parsimoniously place it with the other reduplications (place, time, body parts), all of which can be localized to the non-dominant parietal cortex-rather than with the agnosias, which can be associated with various cortical dysfunctions according to the sensory modality affected.

\section{Richard Abrams}

Department of Psychiatry \& Behavioural Sciences, University of Health Sciences,

The Chicago Medical School,

VA Hospital, Bldg 50,

North Chicago, Illinois 60064

\section{- References}

1. Hayman, M. A. \& Abrams, R. (1977) Capgras' syndrome and cerebral dysfunction. Brit. $\mathcal{F}$. Psychiat., 130, 68-71.

2. Wennstenn, E. A. \& Karn, R. L. (1955) Denial of Illness, pp 48-59). Springfield: Chas. C. Thomas.

\section{ELECTROCONVULSTVE THERAPY}

\section{Dens Sir.}

I recently treated a 62-year-old professional man with a courne of right unilateral ECT. He had made a secions suicidal attempt by overdosage of drugs and had clear-cut signs of endogenoes depression and a history of two previous opisodes of depression for which poychiatric advice had not been sought.

For about I4 years he has suffered from bilateral nerve deafness and tinnitus. These symptoms followed an illwess and were attributed to treatment with stroptomyoin. Having now maintained a good recovery from his depressive episode for eight weeks, he tells me that his tinnitus is much worse and he aseccives it with the application of ECT. I have treated with BCT other patients in his age group who have had deafness and tinnitus and have not had this difficulty described to me previously.

I wonder if any other poychiatrists have encountered such a side-effect?

Woitarn Park Flospitad,

\section{W. J. Charues}

Kirkham, Preston,

Lanes PR4 3AL

\section{MOURNING AFTER PETS}

Drar Str,

I was intercated in Dr Koddie's paper (Foumal, July 1977, pp 21-5). In it he states that 'where such overdependence on a pet does exist there is likely to be a sharp reaction on the part of the owner when the pet dies or has to be "put to sleep" '.
I am at present studying the relationship between children and their dogs. In the results from the 'normal' group, 23 out of 31 parents reported that they had considered the possibility of significant emotional distress occurring (in themselves or the child) if the dog was killed or otherwise permanently lost. This was a factor in their choice of pet, and is statistically significant $(P<0.05$; binomial test, two tailed, corrected for continuity). This suggests that a certain amount of distress is anticipated by the general public at the loss of a pet dog. The mourning described by Dr Keddie is therefore pathological in severity rather than occurrence, and is presumably related to the degree of overdependence, as he implies in his paper. However, degrees of mourning for doge may be more widespread in the community than has been thought.

\section{A. J. Macdonald}

University Department of Psyabiatry,

Ninewells Hospital,

Dundee $D D_{2}$ IUD

\section{LITHIUM INGESTION IN THE POPULATION}

Dear Sir,

At the recent first British Lithium Symposium at Lancaster University, Dr A. I. M. Glen reported that in Edinburgh one citizen in every thousand was regularly taking lithium. In the closing address, Dr R. P. Hullin of Leeds reported, as the result of a broad survey, that nationwide about one in two thousand were on lithium treatment.

The biochemistry laboratory at Crichton Royal has the monopoly of measurement of plasma $\mathrm{Li}$ levels from patients recidont within South West Scotbend, melatively self-contained area with mimimal population mobility. As at $25 \mathrm{Ju}$ ly 1977 there were 113 residents of the area receiving lithium therapy, comprising 93 out-patients, 18 longer-stay in-patients and psychogeriatric day-patients, and 2 recent admissions. From a population of 150,000 the figures reveal that one in every 1,330 persons is receiving lithium therapy.

Department of Clinical Rewearch, J. C. Lrrm: Crichton Royal, Dumfries DGI ${ }_{4} T G$

\section{PLATELET MAO IN SCHIZOPHRENICS WITH AND WITHOUT FAMILY HISTORY OF SCHIZOPHRENIA}

DeAr Sir,

We recently reported ( 1 ) that we were unable to confirm the findings of Murphy and Wyatt (2) of 
low platelet monoamine oxidase (MAO) in schizophrenia. Since that study numerous reports have appeared on platelet MAO in schizophrenia, some able $(3,4,5)$ and others unable $(6,7)$ to confirm the original report of Murphy and Wyatt (2). Since low platelet MAO has been suggested as a genetic marker for vulnerability to schizophrenia (8) it seemed that non-genetic 'phenocopies' of schizophrenia would be expected to lack the marker of low platelet MAO. Since schizophrenia is thought to be heterogeneous in aetiology, it seemed possible that non-genetic phenocopies of schizophrenia without low platelet MAO may be over-represented in studies that find platelet MAO normal in schizophrenia. This might explain the discrepant findings between studies.

To test this hypothesis we evaluated 34 chronic schizophrenic in-patients at the Jerusalem Mental Health Centre. Overlap with the previous study was minimal and diagnostic criteria were identical (I). Eleven paticnts were determined by case paper review and interview of relatives to have a first-degree rclative with schizophrenia; ten patients were determined to have no family history of schizophrenia whatsocver. Thirteen patients had a family relative with a mental illness questionably schizophrenia or a schizophrenic family relative more distantly related than the first degree; these were excluded from the study. A normal control group was selected from hospital employees with no history of mental illness.

Platelet MAO was measured using benzylamine as substrate, as described previously (I). The Table

TABLe

Platelet MAO in schizophrenics with and without family history of schizophrenia

\begin{tabular}{|c|c|c|c|c|}
\hline Group & $\mathrm{N}$ & Sex & Age & $\begin{array}{c}\text { Platelet MAO } \\
\text { (nanomoles } / \mathrm{hr} / \mathrm{mg} \\
\text { protein) }\end{array}$ \\
\hline $\begin{array}{l}\text { Schizophrenics } \\
\text { with first-degree } \\
\text { schizophrenic } \\
\text { relatives }\end{array}$ & 11 & $\begin{array}{l}8 \mathrm{M} \\
{ }_{3} \mathrm{~F}\end{array}$ & $\begin{array}{c}26 \cdot 6 \\
(18-38)\end{array}$ & $\begin{array}{c}49 \cdot 9 \pm 16 \cdot 0 \\
\left(3^{2-87}\right)\end{array}$ \\
\hline $\begin{array}{l}\text { Schizophrenics } \\
\text { with no family } \\
\text { history of mental } \\
\text { illness }\end{array}$ & 10 & $\begin{array}{l}{ }_{7}^{7} \mathrm{M} \\
{ }_{3} \mathrm{~F}\end{array}$ & $\begin{array}{c}32 \cdot 2 \\
(23-39)\end{array}$ & $\begin{array}{c}51 \cdot 0 \pm 20 \cdot 2 \\
\quad(17-86)\end{array}$ \\
\hline Normal controls & 12 & $\begin{array}{l}7 \mathrm{M} \\
{ }_{5} \mathrm{~F}\end{array}$ & $\begin{array}{c}29 \cdot 8 \\
(17-43)\end{array}$ & $\begin{array}{c}44 \cdot 8 \pm 14 \cdot 5 \\
(23 \cdot 71)\end{array}$ \\
\hline
\end{tabular}

shows platelet MAO in schizophrenic patients with and without a first-degree relative with schizophrenia and in the normal controls. The results show no difference in platelet MAO between the 'more genetic' and 'less genetic' groups of schizophrenic patients. Moreover, the results are identical with our previous study, which found platelet MAO slightly, but not significantly, higher in schizophrenic patients than in normal controls ( 1 ). Thus presence or absence of non-genetic phenocopies for schizophrenia cannot explain the discrepant results in the literature.

\section{Robert H. BELMAKer \\ Avi Galon \\ Leon Perḱz}

RichaRd EBStein

$P O B$ 140,

Jerusalem Mental Health Centre,

Jerusalem, Israel

\section{REFERENCES}

1. Belmaker, R. H., Ebstein, R. P., Ebbesen, K. \& Rimon, R. (1976) Platelet monoamine oxidase in schizophrenia and manic-depressive illness. Brit. 7. Psychiat., 129, 227-9.

2. Murphy, D. L. \& Wyatt, R. J. (1972) Reduced MAO activity in blood platelets from schizophrenic patients. Nature, 238, 225-6.

3. Meltzer, H. Y. \& Stahl, S. M. (1974) Platelet monoamine oxidase activity and substrate preferences in schizophrenic patients. Res. Comm. in Chem. Path. Pharmacol., 7, 419.

4. Domino, E. F. \& Khanna, S. S. (1976) Decreased blood platelet MAO activity in unmedicated chronic schizophrenic patients. Amer. F. Psychiat., 133, 323-6.

5. Zeller, E. A., Boshes, B., Davis, J. M. \& Thorner, M. (1975) Molecular aberration in platelet MAO in schizophrenia. Lancet, $i,{ }_{3} 85$.

6. Friedman, E., Shopsin, B., Santhananthan, G. \& Gershon, S. (1974) Blood platelet MAO activity in psychiatric patients. Amer. F. Psychiat., I31, 1392-4.

7. Owen, F., Bourne, R., Crow, T. J., Johnstone, E. L., Bailey, A. R. \& Hershon, H. J. (1976) Platelet MAO in schizophrenia. Arch. gen. Psychiat., 33, 1370-3.

8. Wyatt, R. J., Murphy, D. L., Belmaker, R. H., Cohen, S., Donnelly, C. H. \& Pellin, W. (1973) Reduced monoamine oxidase in platelets: a possible genetic marker for vulnerability to schizophrenia. Science, 179, 916-18. 